УДК $346.91+346.21+347.132$

DOI https://doi.org/10.32849/2663-5313/2020.3.12

Олег Доценко,

студент магістратури юридичного факультету

Киівського начіонального університету імені Тараса Шевченка

\title{
ВИЗНАННЯ НЕДІЙСНИМ ПРАВОЧИНУ, ВЧИНЕНОГО ВИКОНАВЧИМ ОРГАНОМ ГОСПОДАРСЬКОГО ТОВАРИСТВА 3 ПЕРЕВИЩЕННЯМ СВОЇХ ПОВНОВАЖЕНЬ, ЯК СПОСІБ ЗАХИСТУ КОРПОРАТИВНИХ ПРАВ
}

Стаття розвиває позицію Великої Палати Верховного Суду, яка була викладена в постанові від 08.10.2019 р. у справі № 916/2084/17 та яка продовжує втілюватись у практиці Касачійного господарського суду у складі Верховного Суду. Відповідно до останньої вчинення правочину від імені господарського товариства його виконавчим органом без згоди вищого органу управління, у разі коли така згода є необхідню, не може порушувати корпоративні права учасників господарського товариства.

Автор зауважує, що учасники господарсвкого товариства, пред’являючи позов про визнання недійсним правочину господарського товариства, вчиненого від імені останнього його виконавчим органом, обгрунтовують своє право на подання ивого позову своїм статусом як «іншої заінтересованої особи» внаслідок порушення їхніх корпоративних прав. У зв'язку з цим автор обгрунтовує, що об'єктом захисту у такий спосіб захисту, як визнання правочину недійсним, у разі подання позову «іншою заінтересованою особою», яка не є стороною правочину, виступає насправді охоронюваний законом інтерес иієї особи, а не ї̈ суб'єктивне право. Останнє стосується також і позовів учасників господарського товариства про визнання недійсним правочину, вчиненого від імені господарського товариства його виконавчим органом з перевищенням повноважень, оскільки такі учасники намагаються оспорити правочини, сторонами яких вони не є. При цьому автор доводить, що є випадки, коли вчиненням правочину господарським товариством можуть порушуватись охоронювані законом інтереси його учасників, що може бути підставою для визнання такого правочину недійсним. Однак иі випадки не охоплюють вчинення правочину виконавчим органом товариства з перевищенням повноважень, оскільки порушеними у цьому разі будуть інтереси саме господарського товариства, а не корпоративні права чи інтереси його учасників. При цьому автор наголошує, що правочини, вчинені від імені господарського товариства його виконавчим органом без згоди уповноваженого органу управління, наглядової ради чи загальних зборів учасників (акціонерів), можуть бути визнані недійсними саме з підстави невідповідності «волі господарського товариства» його волевиявленню, яке здійснено виконавчим органом товариства без згоди уповноваженого на формування волі товариства органу на вчинення певного правочину.

У статті зроблено висновок, що найбільш оптимальним способом вирішення проблеми із практикою подання учасниками господарських товариств таких позовів $є$ закріплення їхнього права на подання похідного позову в інтересах товариства.

Ключові слова: корпоративні права, визнання недійсним правочину, спосіб захисту, перевищення повноважень, виконавчий орган, господарське товариство, похідний позов, корпоративні спори, охоронюваний законом інтерес.

Постановка проблеми. Як випливає 3 національної судової практики, однією із найбільш проблемних категорій спорів, які відносять до корпоративних, є спори за позовами учасників про визнання недійсними правочинів, вчинених від імені господарського товариства його одноосібним вико- навчим органом або членом колегіального виконавчого органу (далі - виконавчим органом) 3 перевищенням своїх повноважень. Починаючи з 2000-х років домінуюча позиція у судовій практиці щодо цих спорів змінювалась декілька разів, а остання кардинальна зміна позиції у судовій практиці вищих судів 
відбулась наприкінці 2019-го року. Така мінливість судової практики у цих спорах не може не впливати негативно на стабільність господарського обороту в цілому.

При цьому це свідчить про те, що за такий значний проміжок часу не було остаточно вирішено питання можливості застосування у цих спорах такого цивільно-правового способу судового захисту, як визнання недійсним правочину, для захисту саме корпоративних прав, що зумовлює потребу в більш глибокому теоретичному осмисленні домінуючої у сучасній судовій практиці правової позиції щодо цих спорів, а також у формулюванні пропозицій щодо законодавчого вирішення проблеми належного забезпечення інтересів учасників корпоративних відносин у таких спорах.

Метою статті $є$ дослідження проблем застосування такого способу захисту, як визнання недійсним правочину, вчиненого від імені господарського товариства його виконавчим органом з перевищенням повноважень, з метою захисту корпоративних прав учасників господарських товариств, а також розробка пропозицій щодо законодавчого вирішення проблеми застосування вказаного способу захисту у корпоративних конфліктах.

Аналіз останніх досліджень і публікацій. Останніми роками дослідженням тих чи інших аспектів порушеного питання займалися такі відомі науковці-правники, як А. В. Смітюх, Т. М. Штим, О. В. Кологойда, С. С. Томчишен, І. В. Лукач, І. В. Спасибо-Фатєєва, О. Р. Кібенко та інші. Проте постійні зміни позиції вищих судів щодо проблемних питань, які є предметом дослідження цієї статті, строкатість наукових позицій на цю тему свідчать про необхідність подальшого теоретичного осмислення досліджуваної проблеми та розробки пропозицій щодо її вирішення.

Виклад основного матеріалу. Проблема позовів учасників господарських товариств про визнання недійсними правочинів, для вчинення яких необхідна згода вищого органу управління у вигляді загальних зборів учасників (йдеться про «значні правочини» та «правочини із заінтересованістю» О. П.), однак які вчинені виконавчим органом без такої згоди, як зазначалось, є не новою для судової практики України. При цьому погляди щодо можливості захисту корпоративних прав учасників товариства за допомогою такого способу захисту в судовій практиці неодноразово змінювались. Остання зміна позиції вищих судів щодо позовів учасників господарських товариств про визнання недійсним правочину, вчиненого їх виконавчими органами з перевищенням повноважень, 3 посиланням на порушення їх корпоративних прав була відображена у постанові Великої Палати Верховного Суду (далі - ВП ВС) від 08.10.2019 р. у справі № 916/2084/17 [1] У цій постанові ВП ВС зробила висновок, що корпоративні права учасників насправді не можуть бути порушені у такому випадку, оскільки учасники товариства не є стороною таких правочинів, згоду на вчинення, зокрема, значного правочину надають загальні збори учасників товариства як орган управління товариства, який діє від імені товариства і повноваження якого не можуть бути ототожнені 3 корпоративними правами учасників. Вчинення виконавчим органом правочину від імені товариства 3 перевищенням повноважень може свідчити про порушення прав та інтересів самого товариства, а не корпоративних прав його учасників [1]. Слід погодитися 3 такою позицією, оскільки вона відповідає природі господарського товариства як окремого суб'єкта права та особливостям його дієздатності, на противагу протилежній позиції, яка, на жаль, донедавна панувала в судовій практиці України.

Яскравим прикладом втілення такої протилежної позиції, яка є небезпечною для господарського обороту та згідно 3 якою визнаються порушеними корпоративні права учасника вчиненням правочину господарським товариством без згоди загальних зборів, є, зокрема, постанова Верховного Суду України від 01.07.2015 р. у справі №№ 3-327гс15, якою було визнано, що вчинення такого правочину «свідчить про порушення корпоративних прав позивача щодо управління справами товариства, розподілу прибутку товариства (з одержанням своєї частки) від господарської діяльності товариства та погіршення майнового стану товариства, що впливає на права позивача як учасника 3 часткою у статутному капіталі товариства в розмірі $70 \%$ \% [2]. Цей підхід послідовно втілювався у нещодавній практиці Касаційного господарського суду у складі Верховного Суду (далі - КГС ВС), який зауважув, що «акціонер (учасник) товариства може оспорити договір, вчинений господарським товариством, якщо обгрунтує відповідні позовні вимоги порушенням його корпоративних прав» [3], що спірний договір може порушувати інтереси позивача як акціонера «оскільки вартість його акцій залежить від розміру активів товариства, які останнє внаслідок оспорюваного правочину неправомірно відчужило» [4] тощо.

Така позиція, на нашу думку, є помилковою, оскільки вчиненням такого правочину, 
як було вказано вище, жодне із названих корпоративних прав порушеним бути не може. Більше того, така позиція, як нам здається, деякою мірою нівелює правосуб'єктність господарського товариства, яке має власні право- і дієздатність та законні інтереси, оскільки відбувається підміна інтересів самого товариства, від імені якого діють його органи, інтересами його учасників. Задля обгрунтування таких висновків пропонується дати відповідь на такі питання: 1) що є об'єктом захисту у такий спосіб захисту, як визнання недійсним правочину, вчиненого господарським товариством із третьою особою, у разі пред'явлення позову учасником господарського товариства; 2) чи може бути використаний цей спосіб захисту учасниками товариства для захисту своїх прав чи інтересів, а якщо може, то в яких випадках і що саме буде об'єктом захисту.

Для того, щоб дати відповідь на перше питання, необхідно спочатку з'ясувати, що є об'єктом судового захисту за допомогою такого способу захисту, як визнання правочину недійсним за позовом «іншої заінтересованої особи» взагалі (саме в такому статусі виступають учасники, коли оспорюють правочини господарського товариства з третьою особою - О. П.) .

Згідно зі ст. 15 Цивільного кодексу України (далі - ЦК) кожна особа має право не лише на захист свого цивільного права у разі його порушення, невизнання або оспорювання, а й на захист свого інтересу, який не суперечить загальним засадам цивільного законодавства [5]. При цьому ч. 2 ст. 16 ЦК встановлює способи захисту цивільних прав та інтересів, серед яких, зокрема, $є$ й визнання правочину недійсним [5]. Зі змісту цих статей прямо не випливає, які способи захисту повинні застосовуватись для захисту суб’єктивного цивільного права, а які для захисту інтересу, а отже визначення об'єкта захисту за тим чи іншим способом захисту повинно відбуватись з урахуванням особливостей цих способів захисту.

Г. Г. Харченко відносить визнання правочину недійсним до комплексних способів захисту, тобто таких способів захисту, об'єктом яких можуть бути як цивільні права, так й інтереси [6, с. 26 ]. При чому дослідник доходить такого висновку, виходячи 3 ч. 3 ст. 215 ЦК, в якій зазначено, що за умови, якщо недійсність правочину прямо не встановлена законом, але одна зі сторін або інша заінтересована особа заперечує його дійсність на підставах, встановлених законом, такий правочин може бути визнаний судом недійсним (оспорюваний правочин) [5]. 3 останнього випливає, на думку Г. Г. Харченка, що, особа, яка не є стороною правочину, пред'являючи позов про визнання правочину недійсним, просить про захист саме своїх інтересів, а не суб'єктивного права. С. М. Іванова взагалі вказує, що визнання недійсним правочину без застосування наслідків недійсності $\boldsymbol{\epsilon}$ за своєю формою захистом цивільного інтересу [7, с. 25].

Ми погоджуємося 3 думками цих вчених, оскільки видається, що об’єктом захисту у разі застосування досліджуваного способу захисту за позовом «іншої заінтересованої особи» є саме охоронюваний законом інтеpec, а не суб'єктивне право як таке, незалежно від того, чи заявлені лише вимоги про визнання правочину недійсним, чи також нею пред'явлені вимоги про застосування наслідків недійсності правочину.

Як зазначають дослідники категорії охоронюваного законом інтересу як об'єкта захисту, інтерес, навіть перебуваючи під охороною закону чи права, на відміну від суб'єктивного права, не має такої правової можливості, як останнє, оскільки не забезпечується юридичним обов'язком іншої сторони. Законний інтерес відбиває лише легітимне прагнення свого носія до того, що не заборонено законом, тобто тільки його бажання, мрію, потяг до нього, а отже, не юридичну, а фактичну (соціальну) можливість. Це прагнення у межах сфери правового регулювання до користвання якимсь конкретним матеріальним або нематеріальним благом. Відмінність такого блага від блага, яке охоплюється змістом суб'єктивного права, полягає в тому, що користування благом, на яке особа має право, визначається можливістю в рамках закону, а до якого має законний інтерес - без вимог певних дій від інших осіб або чітко встановлених меж поведінки [8, с. 119]. Отже, із цього цілком закономірно випливають такі висновки. По-перше, під час захисту інтересу заходи матеріально-правового характеру, що становлять зміст способу захисту, впливають на правовідносини, учасником яких носій інтересів, які захищаються, не є. Однак при цьому виникненням цих правовідносин порушується законний інтерес володільця цього інтересу. У разі порушення суб'єктивне право, на відміну від законного інтересу, захищається шляхом вжиття заходів впливу на особу, яка $є$ разом із носієм суб'єктивного права учасником тих же правовідносин, тобто до особи, в якої є кореспондуючий суб'єктивному праву юридичний обов'язок, який не був виконаний чи виконаний неналежним чином, що означає порушення суб'єктивного права. По-друге, захист інтересу не призводить до виникнення, зміни, припинення чи реалізації суб'єктивного 
права, а призводить до фактичної, реальної можливості виникнення чи реалізації певного суб'єктивного права. У цьому контексті слушною є думка I. В. Венедиктової, яка зазначає, що інтерес може бути своєрідною передумовою виникнення права і метою його реалізації, тобто виступати як доправова та післяправова категорія [9, с. 113]. Натомість захист суб'єктивного права полягає у вжитті тих чи інших заходів щодо носія юридичного обов'язку, що спрямовані на задоволення тих інтересів, які опосередковані певним суб'єктивним правом, і проявляються у примусу чи стимулюванні порушника до виконання його обов'язку в натурі, чим здійснюється реалізація суб'єктивного права особи, чи притягненні порушника до юридичної відповідальності (наприклад, у відшкодуванні власникові речі збитків особою, яка пошкодила цю річ) тощо.

3 іншого боку, необхідно звернутись до сутності визнання правочину недійсним як способу захисту. Т. І. Ілларіонова, наприклад, зазначає, що фактична правова значимість категорії недійсності полягає в тому, що у ній розкривається зміст заходу захисту, спрямованого на позбавлення конкретної поведінки особи сили юридичного факту [10, с. 16]. Вчена також зазначає, що «застосування оголошення угоди недійсною означає анулювання прав та обов'язків, що виникли у результаті діяння» [10, с. 16]. При цьому заслуговує на увагу думка С. М. Іванової, яка вважає, що не існує підстав для ототожнення визнання недійсним правочину й застосування наслідків його недійсності як одного способу захисту цивільних прав та інтересів [7, с. 25]. Слід погодитися 3 такою точкою зору вчених, оскільки визнання правочину недійсним не зводиться виключно лише до двосторонньої реституції чи інших правових наслідків, які передбачені законом, останні $€$ всього лиш логічним продовження основного правового наслідку визнання правочину недійсним як застосовуваного (судом) способу захисту - позбавлення дії особи сили правочину як юридичного факту, для чинності якого необхідне дотримання встановлених законом умов його дійсності, однак які при цьому дотримані не були, що означає, що правовідносини, виникнення яких передбачалось на підставі певного правочину, анулюються або не виникають.

Із наведеного нескладно помітити, що визнання правочину недійсним має юридичне значення саме для сторін правочину, оскільки саме їх правовідносини зазнають деякої трансформації, натомість для «іншої заінтересованої особи» створюється лише фактична можливість для реаліза- ції її певного суб'єктивного права. У цьому полягає мета захисту охоронюваного законом інтересу такої особи. Визнання правочину недійсним за позовом «іншої заінтересованої особи» не можна назвати захистом суб'єктивного права, оскільки створення фактичної можливості для реалізації певного суб'єктивного права безпосередньо не поновлює суб'єктивні права цієї особи. Протилежне, тобто можливість безпосереднього захисту порушеного права визнанням правочину недійсним за позовом особи, яка не $є$ стороною правочину, означає необгрунтоване розширення меж суб'єктивного права, яке в такому випадку включає в себе заборону чи обмеження зобов'язаним перед таким позивачем-кредитором особам вчиняти інші правочини, що, як правило, не відповідає природі зобов'язальних правовідносин. Останнє, звичайно, є справедливим, якщо при цьому не завдається шкода іншим особам (ч. 3 ст. 13 ЦК) [5], але завдання такої шкоди «іншій заінтересованій особі» вчиненням правочину може бути підставою для визнання цього правочину недійсним лише у разі, якщо воно пов'язано з дефектом тих чи інших умов дійсності правочину, передбачених ст. 203 ЦК [5], а не лише в силу наявності певних суб’єктивних прав. Натомість ці суб'єктивні права є «джерелом» виникнення охоронюваного законом інтересу, який полягає в наявності певного майна у боржника, що $€$ передумовою для реалізації суб'єктивного права «заінтересованої особи». Так, не будьякий інтерес набуває рис охоронюваного законом та підлягає судовому захисту, відповідно. Охоронюваний законом інтерес не опосередкований суб'єктивним правом, але має бути пов'язаним із ним, його захист має бути передумовою для реалізації суб'єктивного права, що полягає саме в створенні для цього конкретних фактичних можливостей. Тобто охоронюваний законом інтерес як об'єкт захисту характеризується тим, що він виходить за межі суб'єктивного права, в чому і полягає його особливість, яку зазначав ще КСУ у своєму рішенні від 1 грудня 2004 р. № 18-рп/2004 у справі № 1-10/2004 [11].

Вищевикладене натепер підтверджується також і судовою практикою. Так, наприклад, у постанові ВП ВС від 18.04.2018 р. у справі № 439/212/14-ц висвітлено правову позицію, відповідно до якої власний інтерес заінтересованої особи полягає в тому, щоб предмет правочину перебував у власності конкретної особи чи щоб сторона (сторони) правочину перебувала у певному правовому становищі, оскільки від цього залежить подальша можливість законної реалізації заінтересованою особою її прав [12]. 
Повертаючись до практики пред’явлення учасником господарського товариства позову про визнання правочину недійсним, вчиненого директором товариства 3 перевищенням повноважень, 3 посиланням при цьому на порушення їхніх корпоративних прав, слід зазначити, що учасник у цьому випадку також виступає як «інша заінтересована особа», а тому можна говорити про порушення вчиненням такого правочину хіба що охоронюваного законом інтересу учасника, який «випливає» із його корпоративних прав, а не про порушення самих корпоративних прав.

А тому всі вищенаведені висновки щодо захисту охоронюваного законом інтересу визнанням правочину недійсним за позовом «іншої заінтересованої особи» $є$ застосовними і щодо вказаних позовів учасників господарських товариств. Масове посилання на «погіршення майнового стану товариства» як підставу позову про визнання недійсним правочину, вчиненого виконавчим органом з перевищенням повноважень, лише підкреслюють справжню мету такого позову, яка полягає в досягненні наявності певного майна у власності товариства, за рахунок якого будуть задоволені майнові корпоративні права учасника.

Не вдаючись до глибокого аналізу корпоративних прав, зазначимо, що однією 3 особливостей останніх полягає в тому що кореспондуючі їм обов'язки покладені саме на господарське товариство. Так, на думку А. В. Смітюха, корпоративні права це завжди права особи щодо корпоративної господарської організації, а також, можливо, інших суб'єктів корпоративних прав щодо корпоративних господарських організацій (за наявності). Тобто насправді корпоративні права як елемент змісту корпоративних правовідносин можуть бути порушені саме невиконанням чи неналежним виконання свого обов'язку основним суб'єктом кореспондуючого корпоративним правам обов'язків - господарським товариством, однак таке порушення може відбутись лише в межах цих обов'язків [13, с. 87]. При цьому зміст жодного $з$ таких обов'язків господарського товариства не полягає в забороні чи обмеженні укладення тих чи інших правочинів.

Тим не менше, на наше переконання, охоронювані законом інтереси учасника господарського товариства можуть бути захищені шляхом визнання недійсним правочину такого товариства з третьою особою. Однак слід тоді визначити підставу визнання недійсним такого правочину, тобто умову дійсності правочину, яка передбачена ч. 1 ст. 203 ЦК [5] і при цьому дотримана не була, чим і було порушено охоронювані законом інтереси учасника господарського товариства. Недійсність правочину скоріше буде пов'язуватись із спрямованістю правочину на завдання шкоди інтересам учасника (ч. 3 ст. 13, ч. 5 ст. 203, 234 ЦК) [5] (тобто фіктивністю - О. П.), а не із перевищенням своїх повноважень виконавчим органом товариства.

При цьому слід мати на увазі, що про захист охоронюваних законом інтересів учасників товариства може йтися лише за наявності зобов'язальних прав вимоги, які походять від майнових корпоративних прав. Останні ж, насправді, мають досить складну правову природу та умовний характер, оскільки виникнення права вимоги на виплату певної грошової суми у вигляді дивідендів чи виділення на користь учасника частини ліквідаційної маси товариства залежить від наявності сукупності передбачених обставин, тобто юридичного складу. Так, Л. Ф. Гатауліна підкреслює «потенційну невизначеність» як права на отримання ліквідаційної квоти (до моменту прийняття рішення про ліквідацію, завершення розрахунків з кредиторами та затвердження остаточного ліквідаційного балансу), так і права на дивіденди (така можливість потребує конкретизації у рішенні загальних зборів про сплату дивідендів) [14, с. 170-171]. Також С. Д. Могілевський підкреслює, що товариство «не може гарантувати своїм учасникам отримання заздалегідь визначеного стабільного доходу, що є природною особливістю комерційного обороту» [15, с. 93]. Викладене вище означає, що для кваліфікації наявності порушеного інтересу учасника господарського товариства необхідно встановити наявність прав вимоги такого учасника до товариства у вигляді вимоги виплатити конкретну суму грошей чи передачі певного майна, які виникають в силу сукупності певних юридичних фактів тощо. Наявність лише статусу учасника товариства не є підставою для захисту його інтересу, що полягає у якнайкращому майновому стані господарського товариства, оскільки такий інтерес не буде охоронюваним законом.

Натомість перевищення повноважень виконавчим органом, в силу чого були завдані збитки товариству, насправді може бути підставою для визнання правочину недійсним саме за позовом самого господарського товариства. Так, на думку авторів підручника 3 цивільного права за редакцією В. I. Борисової, I. В. СпасибоФатєєвої, В. Л. Яроцького, орган юридичної особи - це юридична конструкція, що створюється правом 3 метою дати можливість 
сформувати і виразити волю юридичної особи, відстоювати її інтереси [16, с. 161]. Між юридичною особою і її органом правові відносини не виникають. Дії органу - дії самої юридичної особи. Орган - це законний представник юридичної особи, оскільки його повноваження засновані на вказівках закону і можуть здійснюватися без довіреності. При цьому, на думку цих же авторів, органи юридичної особи за призначенням можуть бути волеутворюючі та волевиявляючі (виконавчі). Зокрема, загальні збори $€$ вищим органом акціонерного товариства, товариства з обмеженою відповідальністю, але вони тільки формують волю останнього, а виражати її може або правління акціонерного товариства - колегіальний виконавчий орган, або одноосібний виконавчий орган [16, с. 162]. Тобто перевищення повноважень виконавчим органом під час вчинення правочину від імені товариства скоріше свідчить про відсутність узгодженості між волею господарського товариства, яка не була сформована у такому випадку в силу відсутності згоди уповноваженого органу, та волевиявленням, здійсненим виконавчим органом, що $\epsilon$ підставою для недійсності правочину відповідно до ст. 215 ЦК [5], оскільки не дотримана одна із умов дійсності правочину згідно з ч. 1 ст. 203 ЦК [5]. При цьому порушуються інтереси саме тієї особи, в інтересах якої діяв такий представник (виконавчий орган), господарського товариства. Останне цілком узгоджується з абз. 1 ч. 3 ст. 92 ЦК [5]. Варто також зазначити, що порушення права учасника на управління справами товариства шляхом участі в загальних зборах також не означає, що оспорюваний правочин вчинений всупереч інтересам товариства та інших його учасників, що було вказано в постанові ВП ВС від 03.12.2019 у справі № 904/10956/16 [17].

Такий висновок всього лиш підтверджує правову позицію ВП ВС, що викладена в постанові від 08.10.2019 р. у справі № 916/2084/17 [1], оскільки у випадку зі зверненням із вказаним позовом з обгрунтуванням погіршення майнового стану товариства такий учасник насправді звертається в інтересах товариства, а не своїх власних інтересів. Тобто насправді такі учасники подають так званий «похідний позов», повноваження учасників на подання якого чинним законодавством не передбачено. Не вдаючись до детальної характеристики такого інструменту, як похідний позов, зазначимо лиш основні ознаки останнього, які слушно виділяє О. І. Чугунова: 1) у визначених законом випадках такий позов подається учасниками, які за звичайних умов не уповноважені представляти юридичну особу; 2) право або охоронюваний законом інтерес належать юридичній особі [18, с. 45].

Сучасним законодавством право на «похідний позов» закріплено у ст. 54 Господарського процесуального кодексу України [19]. Але, як видається, цього замало, оскільки повноцінний та ефективний захист інтересів товариства далеко не завжди може бути здійснений лише шляхом відшкодування збитків. Водночас фактичний інтерес учасника товариства, який полягає у наявності якнайкращого майнового стану товариства, є очевидними та безсумнівним, оскільки від цього безпосередньо залежить обсяг вимог учасника до товариства при настанні необхідних для цього юридичних фактів, а тому відсутність закріплення такого інтересу учасника у праві учасника на «похідний позов» про визнання недійсним правочину, вчиненого виконавчим органом товариства 3 перевищенням повноважень, $€$ явним недоліком сучасного законодавства, який залишає міноритарного учасника без ефективного інструменту захисту інтересів господарського товариства та опосередковано - своїх. Натомість закріплення вказаного права могло б раз і назавжди вирішити ряд проблемних питань практичного та теоретичного характеру, що були описані вище. Тим паче визнання правочину недійсним $€$ легшим для практичного застосування способом захисту, аніж відшкодування збитків, завданих посадовою особою господарського товариства, в чому й полягає потенційна перевага саме такого похідного позову.

\section{Висновки}

Таким чином, виходячи із вищевикладеного, можна зробити такі висновки.

1) Пред'являючи позов про визнання правочину, вчиненого виконавчим органом товариства без згоди уповноваженого органу управління, учасники, як правило, обгрунтовували свої позовні вимоги порушенням своїх корпоративних прав як «інших заінтересованих осіб», які не були стороною оспорюваного правочину, однак насправді apriori об'єктом захисту за цими позовами можуть бути лише охоронювані законом інтереси учасників, а не їхні корпоративні права.

2) Правочин, вчинений товариством із третьою особою, може бути визнано недійсним за позовом учасника, лише якщо цим правочином завдано шкоди охоронюваним законом інтересам учасника господарського товариства, однак підставою недійсності такого правочину в цьому разі буде їх фіктивність, а не факт перевищення повноважень виконавчим органом. 
3) Перевищення ж повноважень виконавчим органом у разі вчинення правочину від імені товариства свідчить про порушення інтересів саме товариства, а не учасників, а тому це може слугувати підставою для визнання такого правочину недійсним лише за позовом товариства або позовом, поданим в його інтересах. Останне зумовлює необхідність закріплення в законодавстві України права учасника на подання похідного позову в інтересах товариства про визнання недійсним правочину, вчиненого виконавчим органом товариства 3 перевищенням повноважень. Саме такий похідний позов може стати ефективним інструментом захисту інтересів товариства та його міноритарних учасників, а також вирішить нарешті ряд проблем теоретичного та практичного характеру. Водночас розмір частки (акцій), яким повинен володіти учасник (акціонер) товариства, щоб мати право подати такий похідний позов, та інші деталі впровадження такого похідного позову в законодавстві України потребують подальшого дослідження.

\section{Список використаних джерел:}

1. Постанова Великої Палати Верховного Суду від 8 жовтня 2019 р. у справі № 916/2084/17. URL: http://www.reyestr.court.gov.ua/Review/ 84911545 (дата звернення: 11.12.2019).

2. Постанова Судової палати у господарських справах Верховного Суду України від 1 липня 2015 р. у справі № 3-327гс15. URL: http:// www.reyestr.court.gov.ua/Review/46078534 (дата звернення: 11.12.2019)

3. Постанова Верховного Суду у складі колегії суддів Касаційного господарського суду від 16 травня 2018 р. у справі № 916/2872/16. URL: http://www.reyestr.court.gov.ua/Review/ 74203805 (дата звернення: 11.12.2019).

4. Постанова Верховного Суду у складі колегії суддів Касаційного господарського суду від 12.06.2018 р. у справі № № 927/976/17. URL: http://www.reyestr.court.gov.ua/Review/ 74670250 (дата звернення: 12.12.2019).

5. Цивільний кодекс України : Закон України від 16 січня 2003 р. № 435-IV / Верховна Рада України. Відомості Верховної Ради України. 2003. № 40-44. Ст. 356.

6. Харченко Г. Г. Речовий інтерес як об'єкт захисту в цивільному праві України. Вісник Верховного Суду України. 2015. № 12 (184). C. 24-29.
7. Іванова С. М. Визнання недійсним правочину як спосіб захисту цивільних прав та інтересів за законодавством України : дис. ... канд. юрид. наук: 12.00.03. Київ, 2014. 232 с.

8. Чепис О. I. «Законний» та «охоронюваний законом» інтереси: проблеми розмежування. Науковий вісник Ужгородського начіонального університету. 2011. Вип. № 17. С. 118-123.

9. Венедиктова І. В. Співвідношення суб'єктивного права і законного інтересу в цивільному праві. Право і Безпека. 2005. Т. 4 № 3. С. 110-113.

10. Илларионова Т. И. Система гражданскоправовых охранительных мер : автореф. дисс. ... д-ра юрид. наук: 12.00.03. Свердловск, 1985. 417 с.

11. Рішення Конституційного Суду України у справі за конституційним поданням 50 народних депутатів України щодо офіційного тлумачення окремих положень частини першої статті 4 Цивільного процесуального кодексу України (справа про охоронюваний законом інтерес) від 1 грудня 2004 p. № 18-рп/2004 у справі № 1-10/2004. URL: https://zakon.rada.gov.ua/laws/show/ v018p710-04 (дата звернення: 22.12.2019).

12. Постанова Великої Палати Верховного суду від 18 квітня 2018 р. у справі № 439/212/14-ц URL: http://www.reyestr.court.gov.ua/Review/ 73598900 (дата звернення: 22.12.2019).

13. Смітюх А. В. Корпоративні прав та корпоративні паї (частки): теоретико-правові засади : дис. ... док. юрид. каук : 12.00.04. Одеса, 2018. 561 c.

14. Гатаулина Л. Ф.К вопросу о правовой природе корпоративных прав. Вестник Саратовской государственной юридической академии. 2016. № 4(111). С. 167-172.

15. Могилевский С. Д. Общество с ограниченной ответственностью: законодательство и практика его применения. Москва : Статут, 2010. $421 \mathrm{c}$

16. Цивільне право : підручник : у 2 т. / В. І. Борисова (кер. авт. кол.), Л. М. Баранова, Т. І. Бєгова та ін. ; за ред. В. І. Борисової, І. В. Спасибо-Фатєєвої, В. Л. Яроцького. Харків: Право, 2011. Т. 1. 656 с.

17. Смірнов Г. Похідний позов: особливості та проблеми правового регулювання в Україні. Підприємниитво, господарство і право. 2019. № 6. C. 44-51.

18. Постанова Великої Палати Верховного Суду України 03.12.2019 у справі № 904/10956/16. URL: http://www.reyestr.court.gov.ua/Review/ 86333853 (дата звернення: 03.03.2020).

19. Господарський процесуальний кодекс України : Закон України від 6 листопада 1991 р. № 1798-XII / Верховна Рада Украйни. URL: https:// zakon.rada.gov.ua/laws/show/1798-12 (дата звернення: 03.03.2020).

The article develops the position of the Grand Chamber of the Supreme Court, which was stated in the ruling of 08.10.2019 in Case № 916/2084/17 and continues to be incorporated into the practice of the Commercial Cassation Court. According to the position, the legally binding transaction made on behalf of a company by its executive body without the consent of the supreme management body, where such consent is necessary, can not violate the corporate rights of the shareholders of the company. 
The author points out that the shareholders of a company, by filing a claim for invalidation of a legally binding transaction of a company made on behalf of the latter by its executive body, justify their right to file this claim with their status as "other interested person" as a result of violation of their corporate rights. In this connection, the author proves that the object of protection of such a method of protection as the invalidation of a legally binding transaction, in the case of filing a claim by "other interested person" who is not a party to a legally biding transaction, is actually a law guarded interest of that person, not a equitable right. The latter also applies to actions by shareholders of a company for invalidation of a legally binding transaction made on behalf of a company by its executive body in excess of powers, as such shareholders try to invalidate the legally binding transactions to which they are not parties.

At the same time the author argues that there are cases when making of a legally biding transaction by a company may violate a law guarded interest of its shareholders, which may be a ground for invalidation of a legally binding transaction. However, these cases do not cover the legally binding transaction made by the executive body of the company with excess of powers, since in this case the interests of a company will be violated, not the corporate rights or interests of its shareholders. At the same time, the author emphasizes that legally binding transactions made on behalf of a company by its executive body without the consent of the authorized management body, supervisory board or general meeting of participants (shareholders), can be invalidated precisely because of the incompatibility of the "will of the company" with expression of such will, which is carried out by the executive body of the company without the consent of the management body authorized to form the will of the company body to make a certain legally binding transaction.

The article concludes that the most optimal way to solve the problem of the practice of filing such claims by shareholders of a company is to secure their right to file a derivative claim in the interests of the company.

Key words: corporate rights, invalidation of legally binding transaction, method of protection, excess of powers, executive body, business company, derivative claim, corporate disputes, law guarded interest. 